\title{
FACTORIZATION METHODS APPLIED TO CHARACTERIZE THE SOURCES OF VOLATILE ORGANIC COMPOUNDS IN MONTREAL, QUEBEC
}

\author{
EUGENIUSZ PORADA ${ }^{1}$ and TERMEH KOUSHA ${ }^{2}$ \\ ${ }^{1}$ University of Québec at Outaouais, Gatineau, Canada \\ Department of Computer Science \\ ${ }^{2}$ Ottawa University, Ottawa, Canada \\ Department of Mathematics and Statistics
}

\begin{abstract}
Objectives: The study objective was to assemble emission characteristics of the sources of the ambient volatile organic compounds (VOCs) and to elaborate methods of organizing them into the sources' chemical profiles. Material and Methods: The UNMIX - sensor modeling method from the U.S. Environment Protection Agency (EPA) - was used to process the VOC concentration data acquired over the years 2000-2009 for 175 VOC species in 4 air quality monitoring stations in Montreal, Quebec. Results: The method enabled to assess VOC emissions from the typically distributed sources existing in urban environment and VOC occurrences characterizing the local, or point-like, sources. The distributed sources were inextricably associated with hydrocarbons from exhaust, heavier hydrocarbons from contaminated urban soil, fugitive evaporations of gasoline and liquefied petroleum gases (LPG), leakage from the industrial and commercial use of solvents, and the inert, ozone depleting gases permeating urban atmosphere. The sources' profiles were charted involving 60-120 VOC species per source. Spatial distribution of the sources was examined. Conclusions: The UNMIX application and the source profiling methods, by building robust chemical profiles of VOC sources, provided information that can be used to assign the measured VOC emissions to physical sources. This, in turn, provides means of assessing the impact of environmental policies, on one hand, and of industrial activities on the other hand on VOC air pollution.
\end{abstract}

Key words:

Volatile organic compound, UNMIX, Receptor modeling, Source profile, Pulp industry, Principal components

\section{INTRODUCTION}

Man-made volatile organic compounds (VOCs) contribute significantly to the urban air pollution. Widely occurring VOCs, such as e.g., benzene, ethylbenzene, xylenes, 1,1,1-trichloroethane, trichloroethylene, tetrachloroethylene, carbontetrachloride, chloroform, are toxic and/or carcinogenic substances [1-3]. In large cities, harmful effects of increasing ambient concentrations of pollutants are even more dangerous to the public health due to the extent of exposure in the densely populated areas [1,4-10]. Atmospheric photochemistry converts the more reactive VOCs by oxygenation and through reactions with oxides of nitrogen to secondary VOCs, free radicals, ozone, and subsequently to smog organic aerosols $[6,11,12]$.

Correlating VOC emissions from anthropogenic sources with public health indices allows to assess the impact of VOC pollution on human health. The research

Received: November 14, 2014. Accepted: January 24, 2015.

Corresponding author: E. Porada, 1081 Alenmede Cr., Ottawa ON, K2B 8H2, Canada (e-mail: eporada@hotmail.com). 
provides guidelines for planning emission control strategies. Achieving reduction in VOC concentrations in the ambient air comparable to the reduction of the "classic" pollutants (from 1970 to 2008 particulate matter concentration in the ambient air has decreased by over $50 \%$ [13,14]) seems feasible.

Source apportionment of numerous VOC species have already been examined [15-24]. The research presents the methods of modeling the ambient VOC multi-receptors operating in the air quality monitoring stations. The chief methods applied are the Principal Component methods - mainly the Positive Matrix Factorization (PMF). Also Chemical Mass Balance (CMB) system provides methods of modeling the receptors [25,26]. The methods consist in constructing sources' chemical fingerprints - employing a menu of VOCs - in a form of sources' emission profiles, relying on the user-specified inventory of the sources contributing to the measured totals.

The intricacies of organic air pollution and complex atmospheric chemistry make it challenging to build a reliable receptor model [26-29]. The VOC menu typically lists the most prominent VOCs, with high signal/noise ratio (SNR), which allow a clear-cut profiling of the sources. Thereby, some point sources, particularly the specialized industrial plants and the associated waste streams, which yield quite distinct chemical fingerprints of low-concentration VOCs, may stay unresolved.

This research addresses the issue by developing robust source discrimination routines, which also search for the low-emission sources that stay out in the usual hydrocarbon background in the urban air. This is achieved by applying principal component (PC) methods implemented by the U.S. Environmental Protection Agency (EPA): EPA UNMIX [30], which has the advantage over the other PC methods of telling the user which modeling attempt cannot be successful, thus, narrowing the output to the reliable receptor models.

\section{MATERIAL AND METHODS}

\section{VOC measurements and data}

As part of the National Air Pollution Surveillance (NAPS) federal program in Canada [31], air quality monitoring stations were installed across the country, several of them in Montreal, Quebec. The sensors operate basing on gas chromatography/flame ionization detector system (GC/FID) for quantification of light hydrocarbons in the $\mathrm{C} 2$ fraction, while a combined gas chromatography/ mass selective detector (GC/MSD) system operating in selected ion monitoring (SIM) mode is used for quantification of heavier hydrocarbons, in the $\mathrm{C} 3$ to $\mathrm{C} 12$ fractions. The data used for this report consists of daily averages of VOC species concentrations in the ambient air. Measurements of 175 species were taken each 6th day in 4 monitoring stations located in the Great Montreal area (Figure 1). The concentrations are expressed in micrograms per cubic meter.

Stations 2 (No. 50104) and 3 (No. 50115) are located in downtown areas, close to a large body of water, one of them, i.e., station 2, is adjacent to a large multi-industrial park. Station 1 (No. 50103) is located in the East Montreal

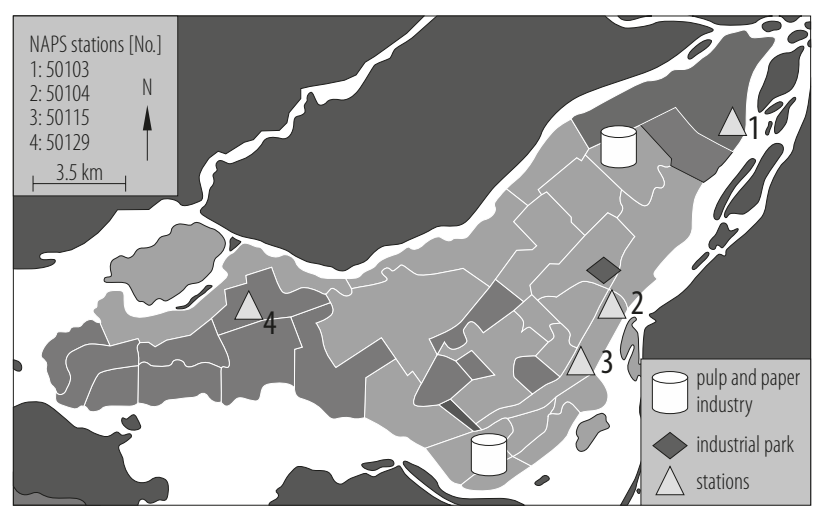

Montreal-East (station 1) - petrochemical industry district; light grey (stations 2,3) - densely populated urban area; dark grey - green terrains, suburbs, and semi-rural districts in the inner ring (station 4); white - body of water surrounding inner-ring Downtown Montreal.

Fig. 1. Demarcation of districts and localization of the National Air Pollution Surveillance (NAPS) monitoring stations in Montreal, Quebec 
zone, formerly a borough of Montreal, a concentration of the petrochemical and chemical industries in the Great Montreal area. Station 4 (No. 50129) is located on the peripheries of Montreal, in a more countryside-like region, but crossed by highways. In the neighborhood there is also a pharmaceutical industry.

This report concerns VOC measurements taken over the years 2000-2009, during the period when effects of implementation of several international and federal clean-air programs $[14,32,33]$ were already clearly visible. The number of all the measured VOC species in each station was 175 , but many measurements bore errors. In this research, only the species that have $95 \%$ or more correct daily averages in the study period were considered. Therefore, the number of VOCs adequately measured and processed varies between 103 and 130, depending on the monitor.

\section{U.S. EPA VOC data processing routines}

The United States EPA makes 2 data processing applications based on the Principal Component method, i.e., EPA PMF and EPA UNMIX available. The methods perform linear modeling of many variables (VOC measurements) with a few expressly constructed predictors or factors - which are alleged apportionments of the measured emissions among putative sources. The applications impose restrictions on the factors they generate in order to make the claim that the factors represent physical sources (and not only one of the large number of mathematically correct solutions to the modeling problem) realistic. This study exploits mainly UNMIX.

The UNMIX applies stronger than PMF's requirements on the correlations between VOCs to consider them as coming from the same source, which makes successful models more reliable. UNMIX deduces the number of sources from the geometrical properties of the VOC concentration data - this number is more reliable than the user's estimates that PMF requires to supply. UNMIX does not apply the "positive matrix" constraint; the emission profiles allow for negative values. Persistent negative values may signal VOC depletion in the atmosphere.

Finally, UNMIX possesses an important feature, which enables to make robust informed guesses regarding VOC sources: it fails to give results when the particular profiling cannot be made reliable. The success of profiling depends, in an essential way, on the collection of VOC species fed into the routine. By combining all the results from the successful run - thus, combining only partial reliable profiles defined in different limited VOC ranges - more reliable exhaustive chemical descriptions of VOC sources can be produced.

\section{The method of combining partial emission profiles into the sources' extended profiles}

Modeling the 175-VOC multi-receptor with UNMIX required applying the routine several hundred times in order to produce sufficiently exhaustive library of the reliable (according to UNMIX), but only partial (approximately 30 VOCs could be fed at a time into the routine), emission profiles. Thus, 500 to 700 (depending on the monitor) profiles were created to ensure that each of the 100 to 130 correctly measured VOCs participated in a successful profiling. A successful model featured 5 to 8 sources, depending on the VOC menu under scrutiny. Incidentally, a consistency in the UNMIX results was observed: adding a new VOC species to the menu never made the number of supposed sources decrease.

Two partial profiles defined on different lists of VOC species may characterize the same source. If they do, they can be combined into one larger profile characterizing the source with VOCs from both lists. The criteria and the procedure of combining partial profiles (defined on short lists, circa $30 \mathrm{VOCs}$ ), into more exhaustive profiles (60-130 VOCs), are described below.

A profile describes a source of VOC emission in terms of the percentage of the measured total that is attributable 
to this source. Question arises when 2 partial profiles are compatible, i.e., when they describe the same source. For the sake of this research, a heuristic measure of compatibility between the 2 profiles was elaborated.

Usually, the closeness of 2 numeric values a, b is defined in terms of the absolute value of their difference: $|a-b|$. However, for the percent values $0-100 \%$, the distance between $0 \%$ and $40 \%$ (for example) would have more significance than the numerically same distance between $60 \%$ and $100 \%$. Therefore, the distance between 2 percentage values was defined depending on their locations on the percent scale, and gauged using the following scale (in percent): $-50,-20,-5,8,14,21,29,40,52,70,100$, 140 (the values out of $0-100 \%$ appear in order to gauge the $<0$ and $>100$ UNMIX results). The distance between 2 values was set to the number of scale marks separating the values (a mark coinciding with a value was counted as $1 / 2$ ), but only if that number was greater than 2, otherwise it was set to 0 .

The distance between 2 profiles was defined as a normalized weighted sum of distances between the profiles' percentage values assumed on their common domain (on all shared VOCs). Average concentrations of VOC in the study period were taken for the weights. Normalization signified dividing the computed distance by the maximal possible distance, the latter being the number of marks on the scale (12 percentage values) times the sum of the VOC weights on the common domain. Two profiles were compatible (were considered as describing the same source) if, 1st, their distance was $\leq 0.05$ and, 2nd, the overlap of their VOCs was large enough to cover at least $1 / 2$ of the shorter profile. This usually signified at least 15 common VOCs, so incompatibility of 1 common VOC of an average concentration usually disqualified compatibility of the profiles.

Combining proceeded by taking a linear combination of the 2 profiles where they overlapped, and their own values where they did not. It is to be observed that combining involves remembering, for each VOC, how many times it participated in the combining operations so far; if it appeared several times, its present value must be set to the average of all its appearances.

Combining was performed by a dedicated $\mathrm{R}$ program [34]. It has been verified that the collection of the final long profiles did not depend essentially on the way of selecting the "opening" partial profiles and the order of searching the profile libraries.

Two profiles generated by combining cycles were either strongly compatible ( $>95 \%$, meaning distance $<0.05$ ) or quite distant $(<90 \%$ compatible, distance 0.1$)$. (The compatibility measure - the set-up for measuring the distance between 2 profiles - was tuned up to meet these criteria).

\section{RESULTS AND DISCUSSION}

UNMIX results, however in large part compatible with PMF results, offer a new picture. The profiles constructed by the combining procedure are of 2 kinds: long profiles with scarce, or none, negative values, reproducible with PMF to a satisfactory degree (compatibility of $90 \%$ or more), and short profiles featuring significantly more negative values. The number of the long profiles was limited to 6-8, while the short ones (and, basically, notextendable profiles: the profiling with extended VOC menus fails) were as numerous as several dozen. It is argued in the discussion section that the appearance of "negative" sources in UNMIX profiles has a meaning different than "error."

Only the long profiles were tabulated and shown here. However, shorter profiles exhibiting "negative" emissions from unidentified sources are required to balance more than $100 \%$ values of contributions from the reported "positive" sources. A negative value may represent a deficit in the concentration of a species, which is more susceptible to photochemistry than its companions in a given partial profile; the species undergoes losses uncorrelated with emissions, thus, displaying a behavior suggesting 
another source. Assuming that such a mechanism is at work, the percent values reported here would represent the initial, yet unaffected by the journey to the sensor, emissions.

\section{The "traffic" source in Montreal, Quebec}

The "traffic" profiles in Tables 1-4 are labeled T. In all the tables, CAS is the Chemical Abstracts Service registry number.

The center of the Montreal urban agglomeration shows abundant reactive species, which can be associated with exhaust, while in boroughs, where petrochemical industry is located, only more inert combustion products persist. The "traffic" source appears responsible for concentrations of a multitude of C4-C8 alkanes and alkenes, the most prominent being the unsaturated hydrocarbons used for gasoline blending and/or enhancing the octane content. The easiest way to recognize the "traffic" species is to observe their hourly pattern of ambient concentration [18,20-22,24]. When only daily averages are available, the following VOCs can be used as "traffic" source indicators:

- 2-methylpentane, a volatile but pervasive isomer of octane, a flag exhaust gas;

- 1-butene/isobutene, utilized for the production of gasoline blending components, also 2-methyl-2-butene, used in North American specialty blendings;

- hexane, constituting more than $1 \%$ in gasoline;

- pentane, its isomer 2,2-dimethylpropane in particular, constituting more than $1 \%$ in gasoline;

- cyclohexane, produced in exhaust from benzene reacting with hydrogen;

- heptane, and its isomers 2,4-dimethylpentane and 3-methylhexane, components of high-octane gasoline, up to $6 \%$;

- 2,3,4-trimethylpentane, mainly used in aviation industry for production of specialty gasoline, wherein it constitutes circa $2 \%$;
- ethylene, a C2 unsaturated hydrocarbon, which is an important natural plant hormone but also industrially recovered at a large scale from refinery gases, may have a loading in the "traffic" profiles - as a byproduct of gasoline combustion; however, its source appears to be the stationary combustion engines rather than the urban transit.

Heavier unsaturated hydrocarbons in paraffin series, nonane, decane, undecane, and dodecane, may occur in gasoline and in the exhausts - most often the nonane - but they have dominant sources in releases from consumer products (mainly from industrial synthetic building materials and housing equipment [35]), from the industrial waste streams and the contaminated urban soil [36-40], though environmental behavior of the vapors from the subsurface gasoline contamination of soil and groundwater is not a well understood phenomenon.

\section{Industrial park in a downtown area}

The National Air Pollution Surveillance stations 2 (No. 50104) and 3 (No. 50115) (Figure 1) are located symmetrically vis-à-vis pulp and paper industry sites, in a densely populated town center. The pulp and paper industry is represented by 2 large plants. Montreal is also an important administrative center for the pulp, paper, and wood industries in North America.

Figure 1 shows a large industrial park, Technopôle Angus, adjacent to the station No. 50104. Incidentally, this receptor captures VOCs typical of industrial sources. Table 1 shows models for receptors 2 and 3 , employing the same set of VOCs and the same ordering of the set; this was the set of all the VOCs captured in station 3, located at a distance of $2.5 \mathrm{~km}$ from the industrial park. Some of the profiles for station 2 are quite compatible with profiles for station 3, but in the former, "industrial," station 2 new sources appear. Moreover, every profile for the "industrial" station has an extension by up to 30 additional VOCs, which were invisible in station 3 . Table 2 lists additional VOCs for station 2 and their allocation to their sources. 


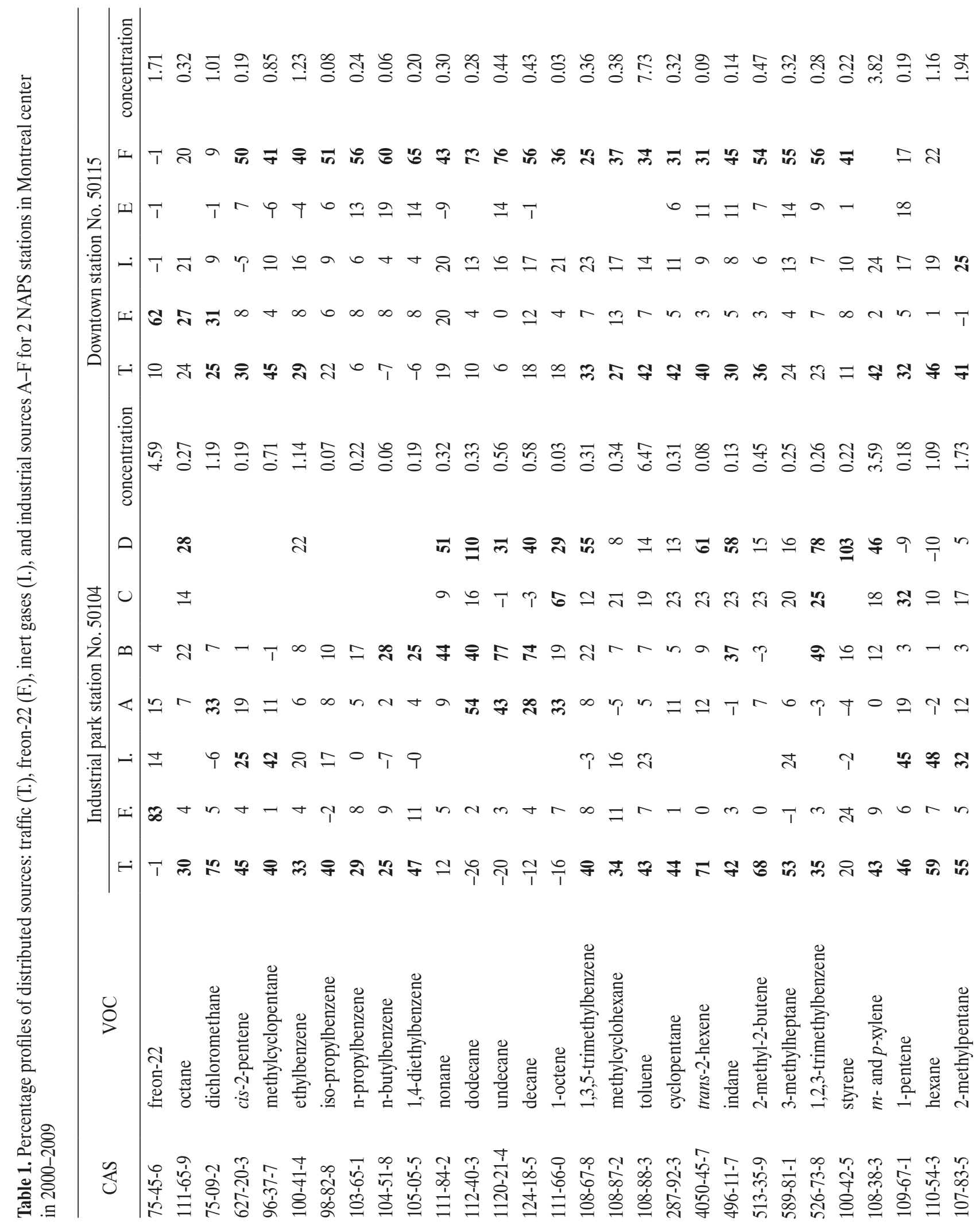




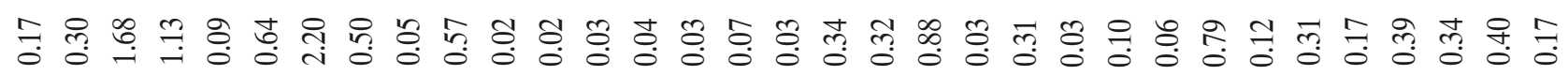

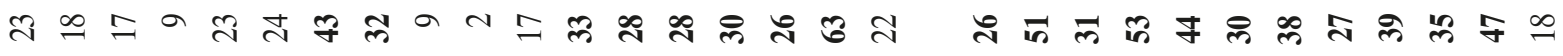

$$
\text { ง十ต ป }
$$

采

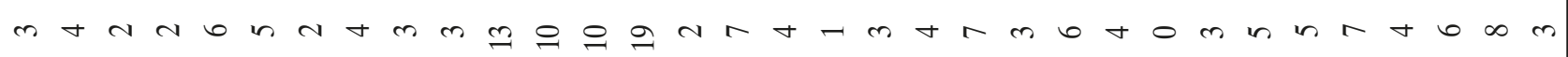

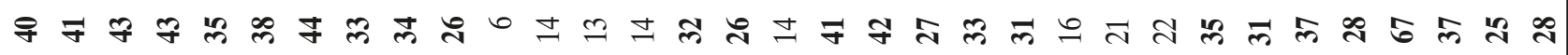

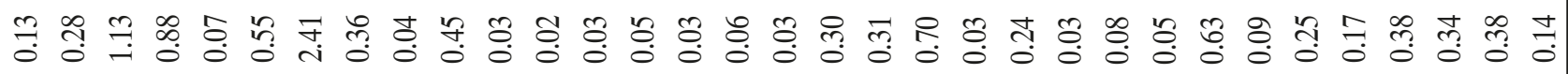
ง

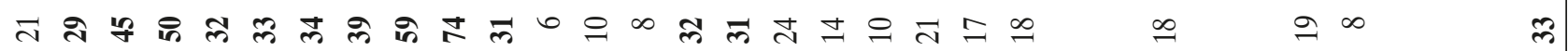
ปค+ ป

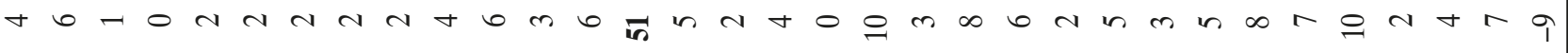
手

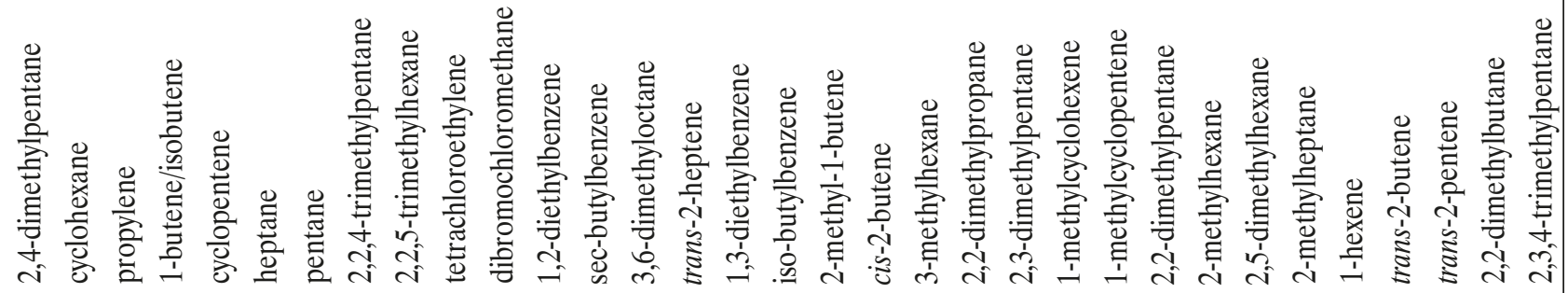

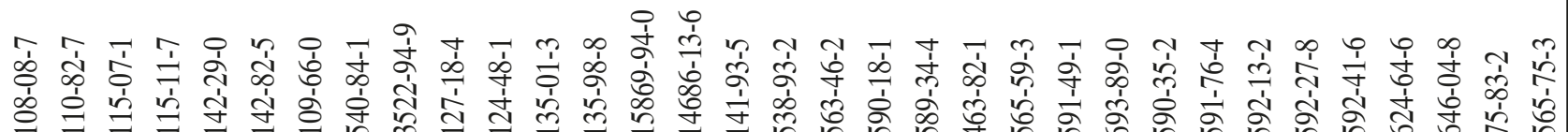




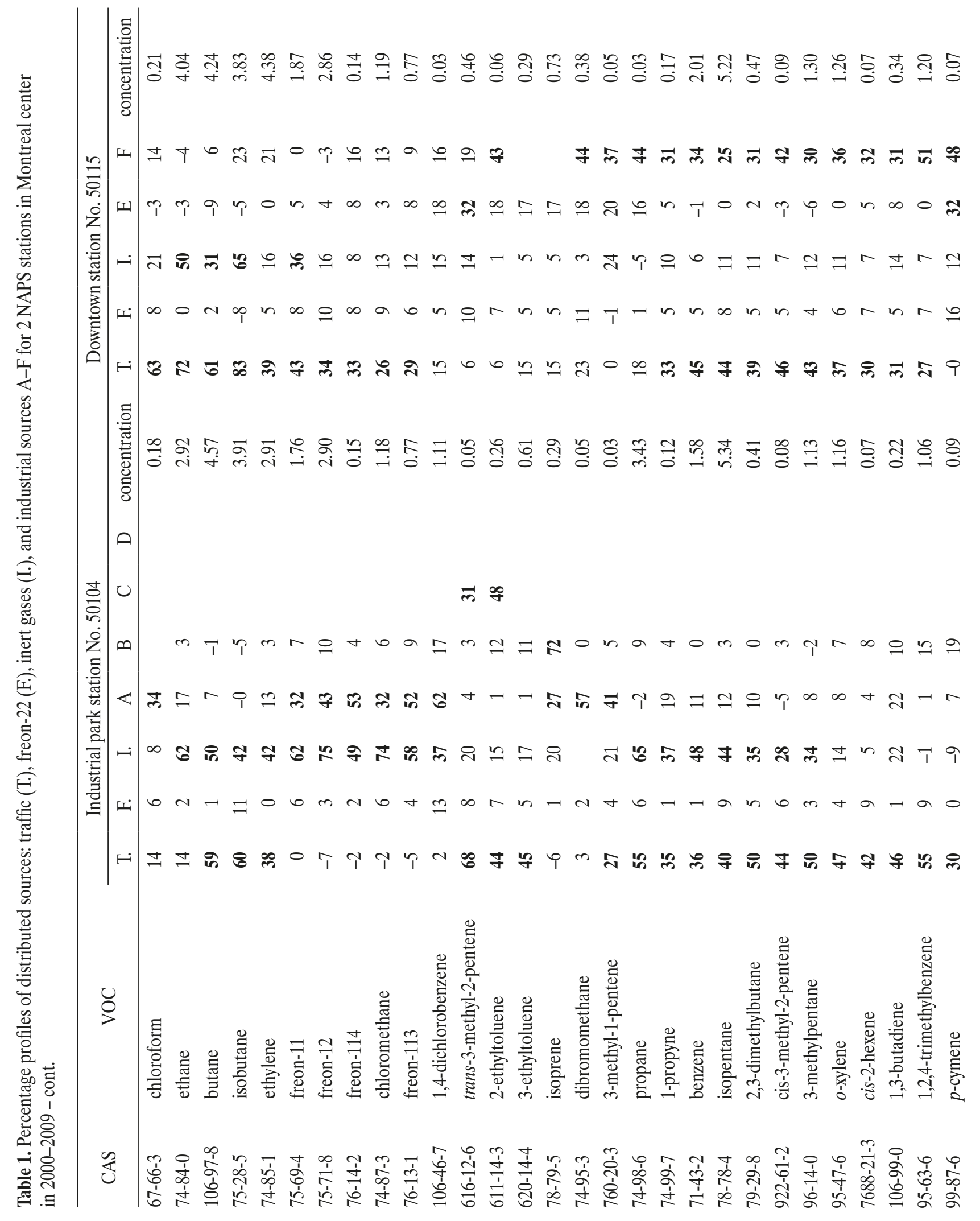




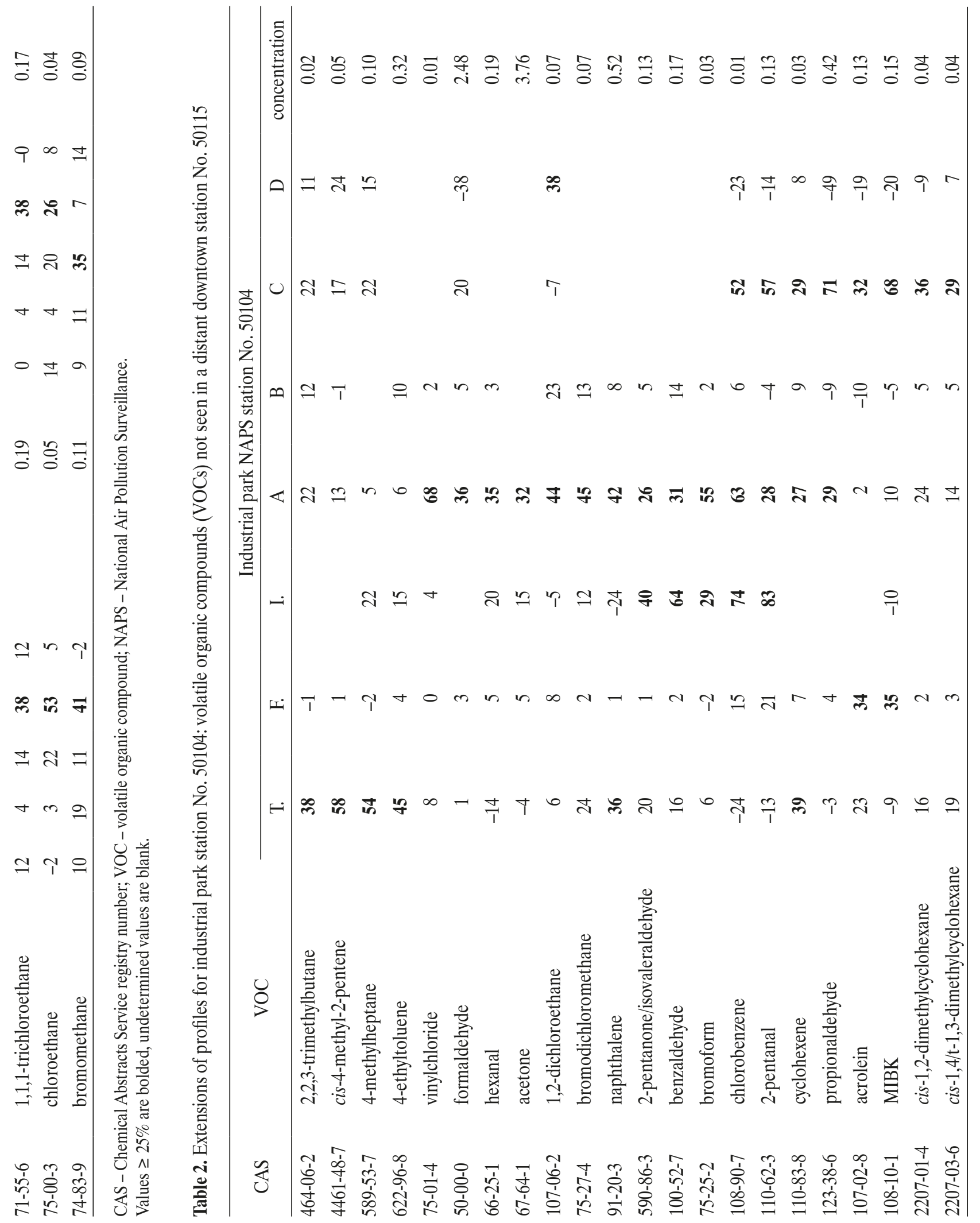




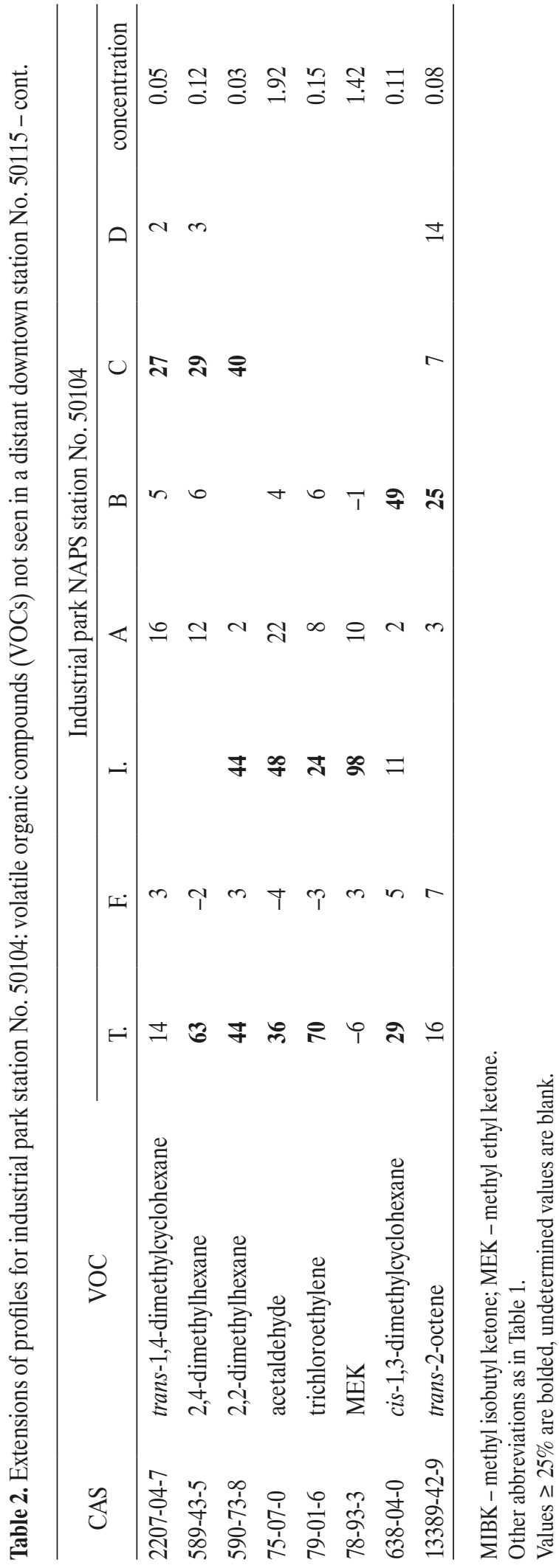

Table 2 briefly presents the local VOC pollution features. And so, trichloroethylene, produced from ethylene (but banned from the food and pharmaceutical industries in the majority of the world due to concerns about its toxicity [41]), here supplements the usual occurrences of ethylene in the urban traffic and in the banks of inert gases. Acetaldehyde, another derivative of ethylene, used in an array of specialized industries manifests a similar behavior. It can be released to the environment during production, use, transportation, and storage. Also power plants, refineries, cement kilns, lumber mills and paper mills release acetaldehyde into the air.

Other aldehydes in Table 2, such as methyl ethyl ketone (MEK), 2-pentanal, and benzaldehyde, accompanied by chlorobenzene, have significant loadings in the "inert gases" profile due to their longer half-life of the reactions with hydroxyl radicals (several days, or months in the case of bromoform, or chloromethane) and/or slow volatilization rate $[42,43]$.

Tables 2 and 3 show profiles labeled F. - for freon-22, which practically alone forms the profiles. This inert gas appears to be a separate source, as it has a different emission pattern from other freons: it supplements the formerly widely used ozone-depleting freon-11 and freon-12 and it escapes to the atmosphere from many of its uses such as: propellant, refrigerant, foaming agent, solvent and degreaser, fire extinguishing agent, and dry cleaning agent. Other freons may form the profile labeled I. - for "Inert," as their longevity allows to detect them long after they were fazed-out.

Profiles A, B, and C in Table 1 (industrial park station 2) and their extensions in Table 2 describe industrial sources located in the nearby industrial zone. The presence of the non-traffic hydrocarbons in paraffin series $\mathrm{C}$-C12, nonane to dodecane are suggestive of industrial sites. Particularly decane, which is universally used in petroleum, gasoline, plastics, rubber, and paper-processing industries, participates widely in organic synthesis, in jet 


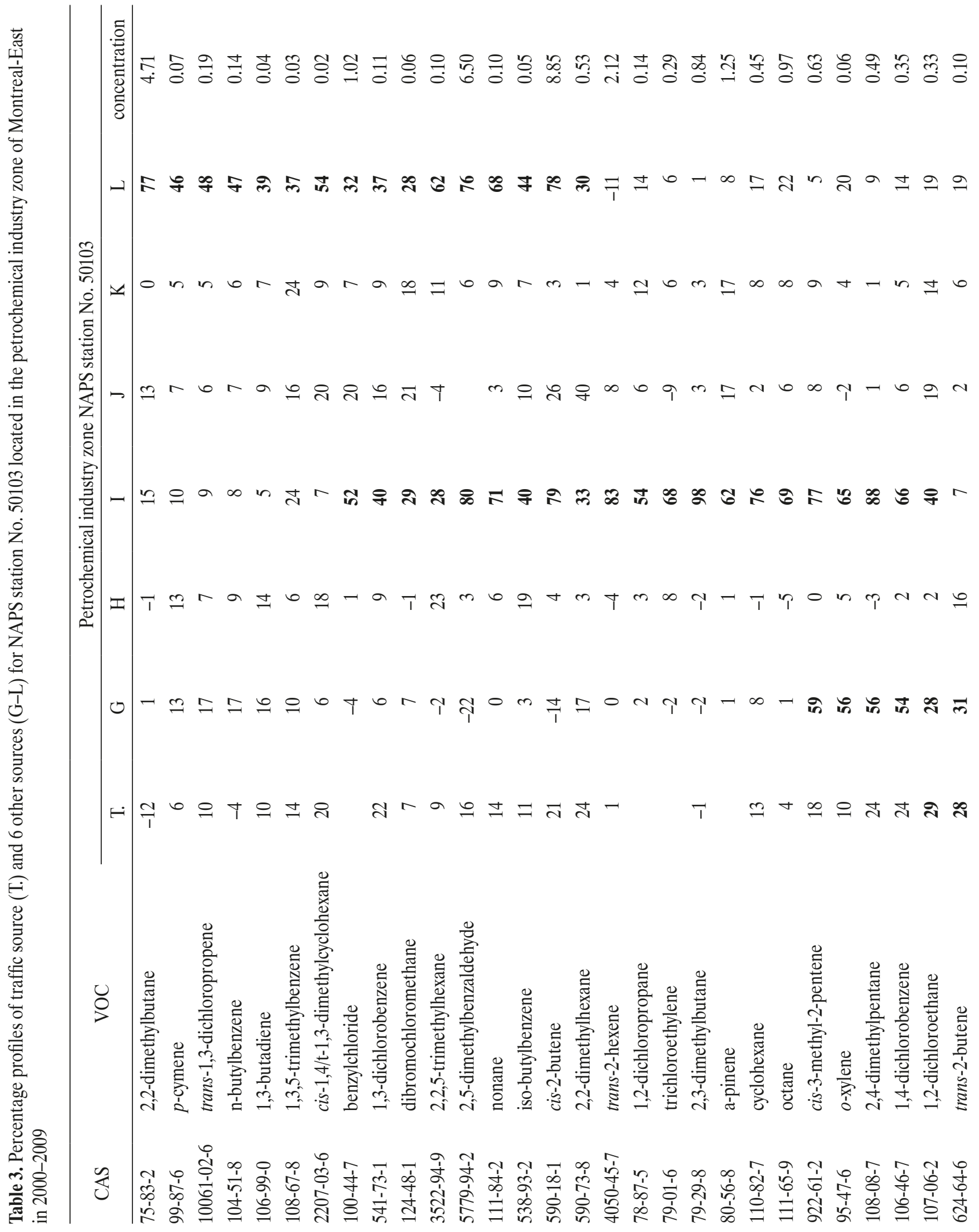




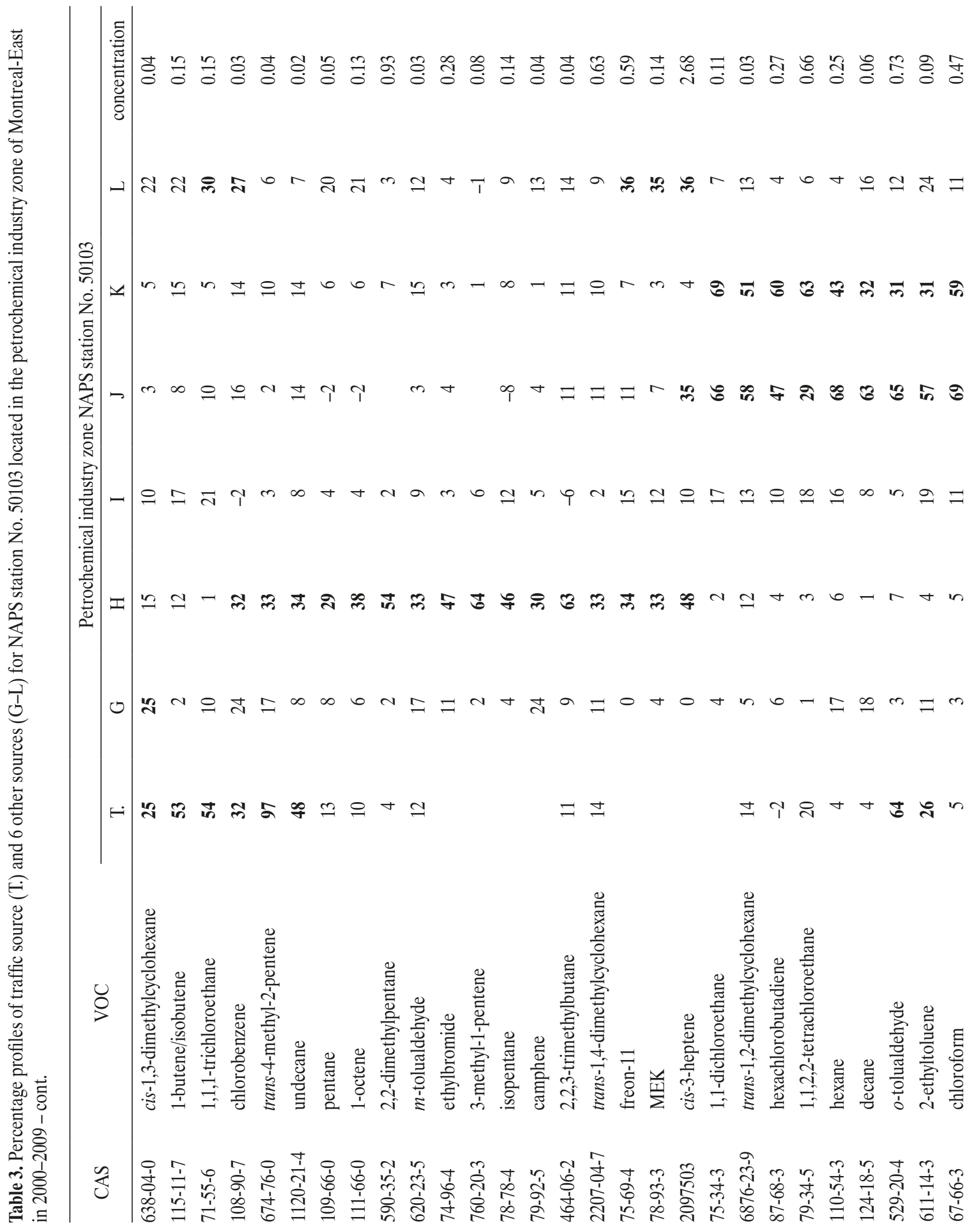




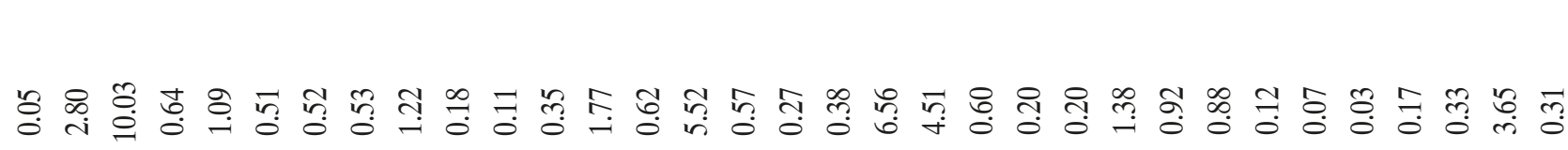

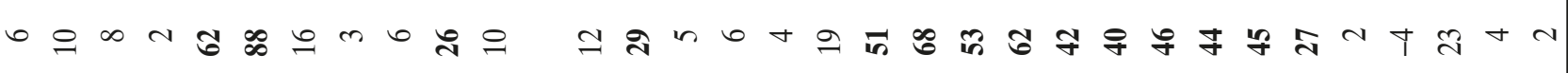
แ่ in สำ่ $r+\rightarrow-m+t m$,

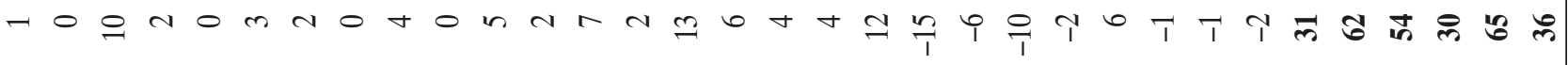

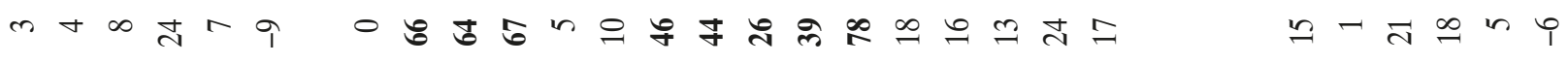

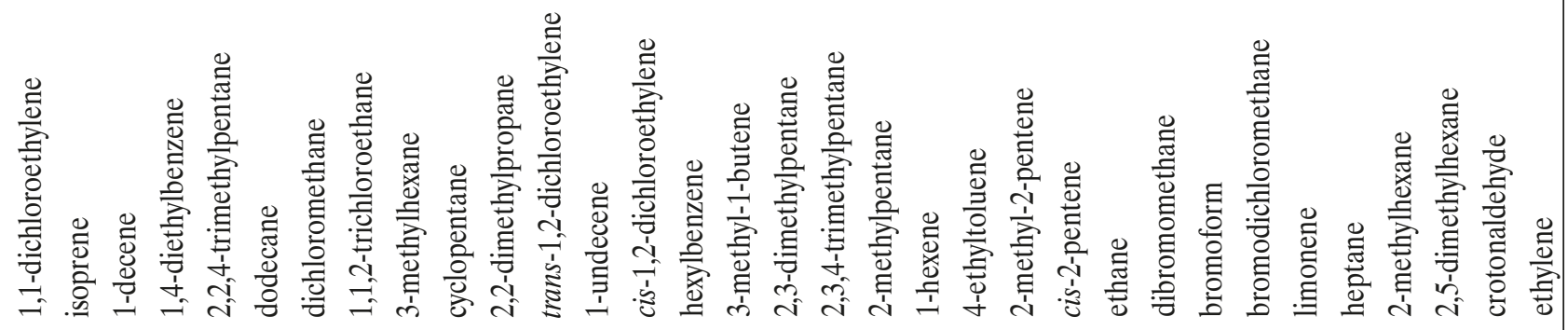

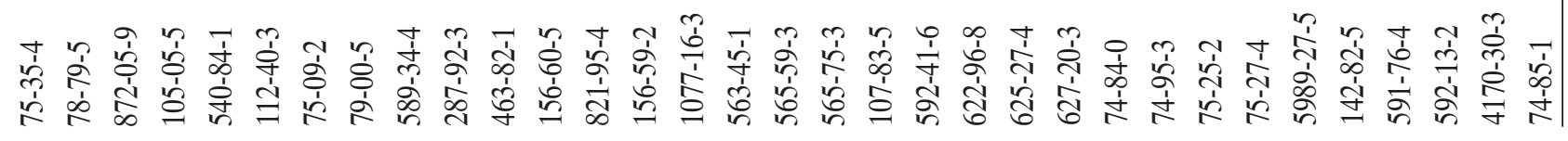




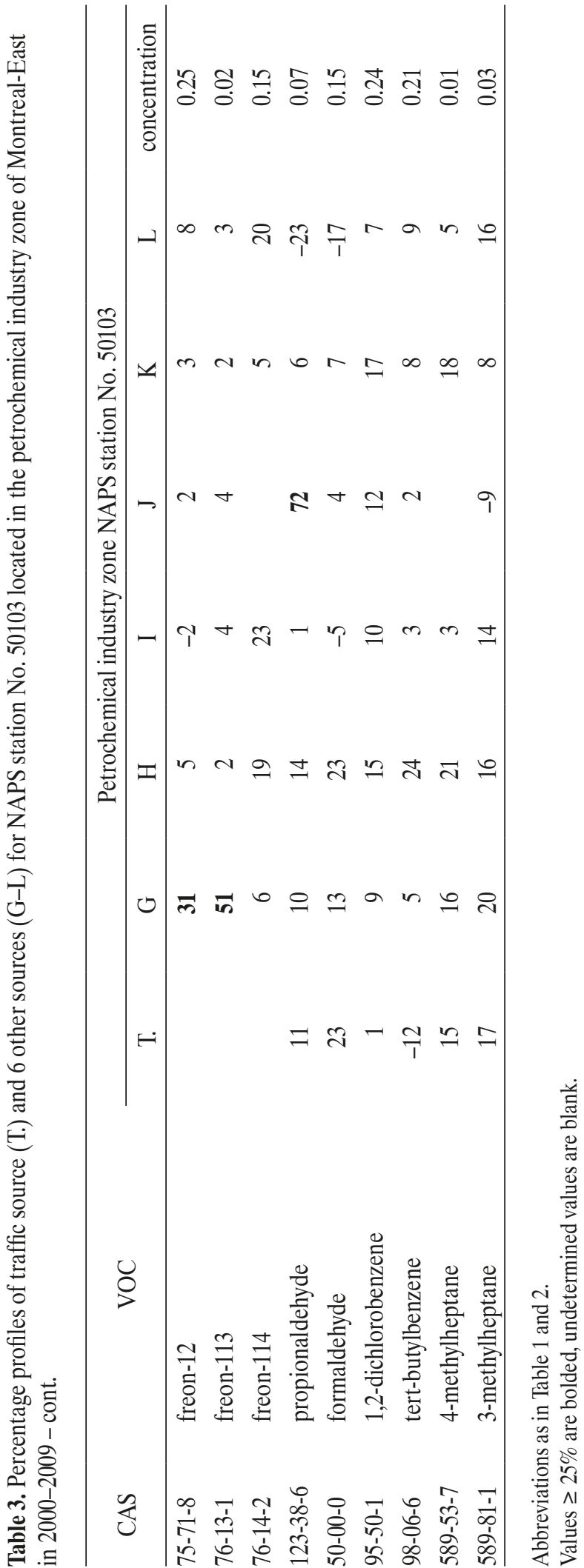

fuel research, and in the manufacturing of paraffin products. It is also used in cleaning agents.

Vinylchloride (highly toxic, flammable, and carcinogenic organochloride, important monomer) and its precursor, 1,2-dichloroethane, as well as naphthalene, chloroethane, and 1,4-dichlorobenzene appearing in source A, suggest local manufacturing of polymer materials, including the polyvinyl chloride (PVC), specialty polymers such as synthetic textile fibers, dyes, and possibly organoaluminum compounds [1,44].

The source corresponding to profile B is characterized by high participation of isoprene in the emission. This hydrocarbon released into the atmosphere by hundreds of million tons by trees, is also a chemical raw material used to make polymeric materials and synthetic versions of the natural rubber.

Profile $\mathrm{C}$ shows numerous compounds used in the research laboratories, in the synthesis of fine organic chemicals, and in the biomanufacturing: 2-pentanal, 1,2-dimethylcyclohexane, cis-1,4/t-1,3-dimethylcyclohexane, and trans-1,4-dimethylcyclohexane. The tetrachloroethylene present here is an excellent solvent for organic materials and degreaser. Methyl isobutyl ketone (MIBK) is used as a solvent for nitrocellulose, lacquers and certain polymers, and resins. Alkene 1-butene/isobutene, besides being used in the production of octanes, is also used to manufacture other chemical products, such as polyethylene, polypropylene resins, polybutene, butylene oxide, and MEK.

Profile D is distinguished by styrene, a precursor to polystyrene and several copolymers. Approximately 7 million tons are produced worldwide annually from ethylbenzene, which in turn is prepared on a large scale by alkylation of benzene with ethylene. Styrene is employed in preparing materials such as rubber, plastic, insulation, fiberglass, pipes, automobile and boat parts, food containers, and carpet backing [45]. Compound 1,3,5-trimethylbenzene, which has shorter half-life time (12 h) than styrene, is still present in the vicinity of petrochemical and 
chemical industrial sites; it is an important solvent used in coatings, cleaners, pesticides, and inks. Alkene trans2-hexene occurs in similar circumstances; however, it is used in smaller quantities and most often in the research facilities.

Columns under "Downtown station No. 50115" in Table 1 show profiles for the station at some distance $(2.5 \mathrm{~km})$ from the industrial park. The T., F., and I. profiles have their versions here, still reminiscent of the corresponding profiles for the "industrial" station 2. Profile E is characterized by strong presence of dibromochloromethane, which is a quite stable trihalomethane (half-life counted in months) appearing in the atmosphere as a by-product of the water treatment and disinfection procedures. The compound may be present nearby a drinking water treatment plant. Profile F is an agglomeration of the "industrial" profiles seen in station 2, which escape a closer analysis. It appears to be the image of the industrial pollution already scrambled by the atmospheric chemistry due to $2.5 \mathrm{~km}$ distance from the pollution sources.

\section{Petrochemical industrial suburb (Montreal-East)}

Montreal-East, formerly a borough, the precincts where petrochemical industry was located, is the East-North extremity of the city of Montreal, Quebec. Three important refineries operated here during the time period for which this analysis was performed. Also the chief petrochemical plants are located in this region.

Table 3 shows the source profiles produced in NAPS station 1 (No. 50103) situated in the Montreal-East industrial zone (time period: 2000-2009). Here, the "traffic" profile is characterized by the "lingering exhaust" fingerprints, consisting of a strong presence of volatile 2-methylpentane in the air, but also of low-volatility cyclopentane. The specialty gasoline component, 2,3,4-trimethylpentane, is also present. Yet the traffic's typical emissions of hexanes, pentanes, heptanes, and octanes are detected only in their most lingering forms and must be assigned to the industrial sources. On the other hand, organochlorides such as 1,1,1-trichloroethane, 1,2-dichloroethylene, and specialty compounds such as 4-methyl2-pentene (which tends to appear in the "traffic" profiles), are arguably the fairly persistent remains of discharges from industrial factories (textile processing and dyeing) rather than from fuel combustion in motor vehicles.

Another characteristic of the petrochemical industry profiles is the absence of emissions of liquefied petroleum gases (LPG): propane, butane, propylene, butadiene, butylene, and isobutylene. Therefore, these emissions, occurring in other regions, appear to be escapes from the consumer widespread usage of LPG.

Petrochemical industry involves petroleum refining processes, creating point-like sources of fugitive organic pollutants and more dispersed sources in a form of effluents and waste streams. The refining processes and operations are of several basic types [46-49]. The 3 predominant ones are: fractionation (distillation into fractions of hydrocarbon compounds of differing boiling-point ranges), dividing molecules by thermal and catalytic cracking, and rearranging molecules with isomerization and catalytic reforming. Combining molecules through alkylation (introducing alkyl groups, such as methyl, $-\mathrm{CH}_{3}$, or ethyl, $-\mathrm{C}_{2} \mathrm{H}_{5}$, group, into organic compound [50,51]), polymerization (converting light olefin gases including ethylene, propylene, and butylene into hydrocarbons of higher molecular weight and higher octane number that can be used as gasoline blending stocks), hydrogenation (addition of hydrogen atoms to the molecule [52,53]), dehydrogenation (catalytic elimination of hydrogen atoms from molecules), gas-phase photochemical reactions, coal carbonization, and many other reactions most often involving ethylene or benzene [54-56] also has great technological importance.

It appears that the processes result in releasing a plethora of compounds that usually are reported to us as "solvents" [47,57] into the environment. Specialty solvents and useful intermediates such as 2-methyl-2-pentene, 
cis-3-methyl-2-pentene, 2,4-dimethylpentane, trans-4-methyl-2-pentene, trans-2-hexene, cis-1,4/t-1,3-dimethylcyclohexane, cis-2-pentene, iso-butylbenzene, 2-ethyltoluene, or 4-ethyltoluene can be observed. It is not known to the authors if the compounds are targeted in the refinery operations, or if they are by-products.

Other compounds, such as octane, heptane, 2,4-dimethylpentane, 2,2-dimethylpentane, 1,4-diethylbenzene, 2-methylhexane, 3-methylhexane, 1-hexene are clearly targeted in operations of distillation, while nonane, dodecane, cis-2-butene may come from the cracking, distillation, and/or catalytic dehydrogenation operations. Also 2,2-dimethylbutane, 2,3-dimethylbutane, 2,2,4-trimethylpentane are targeted in the operations of alkylation of ethylene. Benzylchloride is targeted in photochemical reaction of toluene with chlorine. Cyclohexane is produced by hydrogenation of benzene, and xylenes are targeted in the processes of catalytic reforming and coal carbonization.

Table 3 exhibits a number of species occurring only in this zone. Apart from $p$-cymene, there also appear monoterpenes camphene and a-pinene, however, indicating separate sources. They are probably sequels of wood pulping and traditional timber industry, or the naturally occurring wood terpenes.

Aldehydes such as propionaldehyde, tolualdehydes, and MEK come from those sources, rather than from traffic or petrochemical plants. On the other hand, other aldehydes, crotonaldehyde and 2,5-dimethylbenzaldehyde - important building blocks in the organic chemistry - are probably produced in refinery operations.

Refineries also produce important intermediates in the manufacture of chlorinated pesticides and solvents, chloroform, bromoform, dichloromethane, bromodichloromethane, dibromomethane, 1,1-dichloroethane, 1,1,2,2-tetrachloroethane, 1,2-dichloropropane, and trans1,3-dichloropropene [1], while hexachlorobutadiene is released as a by-product in the manufacture of the chlorinated solvents. Occurrence of trichloroethylene, 1,1,2-trichloroethane, and 1,1-dichloroethylene, which arise in some refinery processes, here, most likely, are results of operations of a textile industrial unit.

\section{Suburban district}

Table 4 presents a model for the peripheral station 4 (No. 50129), located in a suburban district surrounded by agglomerations of pharmaceutical companies and research laboratories (almost 200 pharmaceutical companies are located in and around Montreal). The model shows typical distributed sources: T. (traffic), F. (freon-22), I. (inert), but also a local source of emissions characteristic for organic synthesis in the pharmaceutical industry, labeled Pha. Indeed, the manufacture of pharmaceutical products involves mainly species such as: decane, 2-, 3-, 4-ethyltoluene, 1,2,3-trimethylbenzene, isobutylbenzene, indane, and also chloroform - a common solvent used in a laboratory.

A separate source, labeled Ch. for "Chemical manufacturing" is distinguished by the compounds such as 3-methyl-1-pentene, bromoform, dibromomethane, freons, and 1,2-dichloropropane, which are important intermediates in the production of many chlorinated chemicals, mainly solvents, degreasers and pesticides.

Finally, source $X$ cannot be easily qualified. It is distinguished by a massive emission of ethylene, simple unsaturated hydrocarbon $\left(\mathrm{C}_{2} \mathrm{H}_{4}\right)$ widely used in the petrochemical and chemical industries, and 1-propyne $\left(\mathrm{C}_{3} \mathrm{H}_{4}\right)$ a specialty fuel for not-industrial application, extremely flammable unsaturated aliphatic alkyne.

\section{Citywide features of the hydrocarbon pollution}

Short chain haloalkanes such as dichloromethane and dibromomethane, very common solvents and reagents, formerly widely used in preparation of pesticides and fumigants - but toxic when released to the atmosphere - appear in all the 4 stations in Montreal and have manifold 


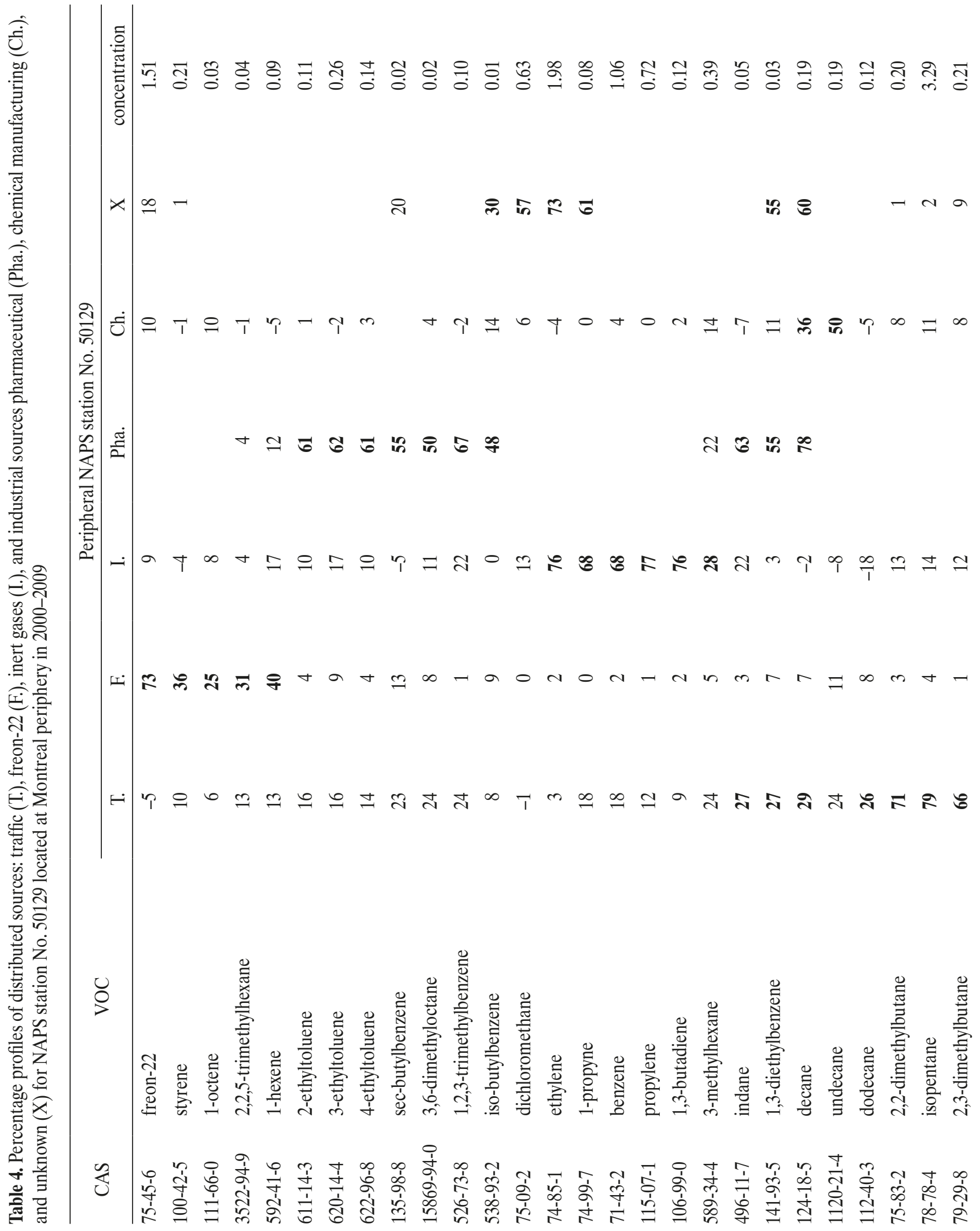




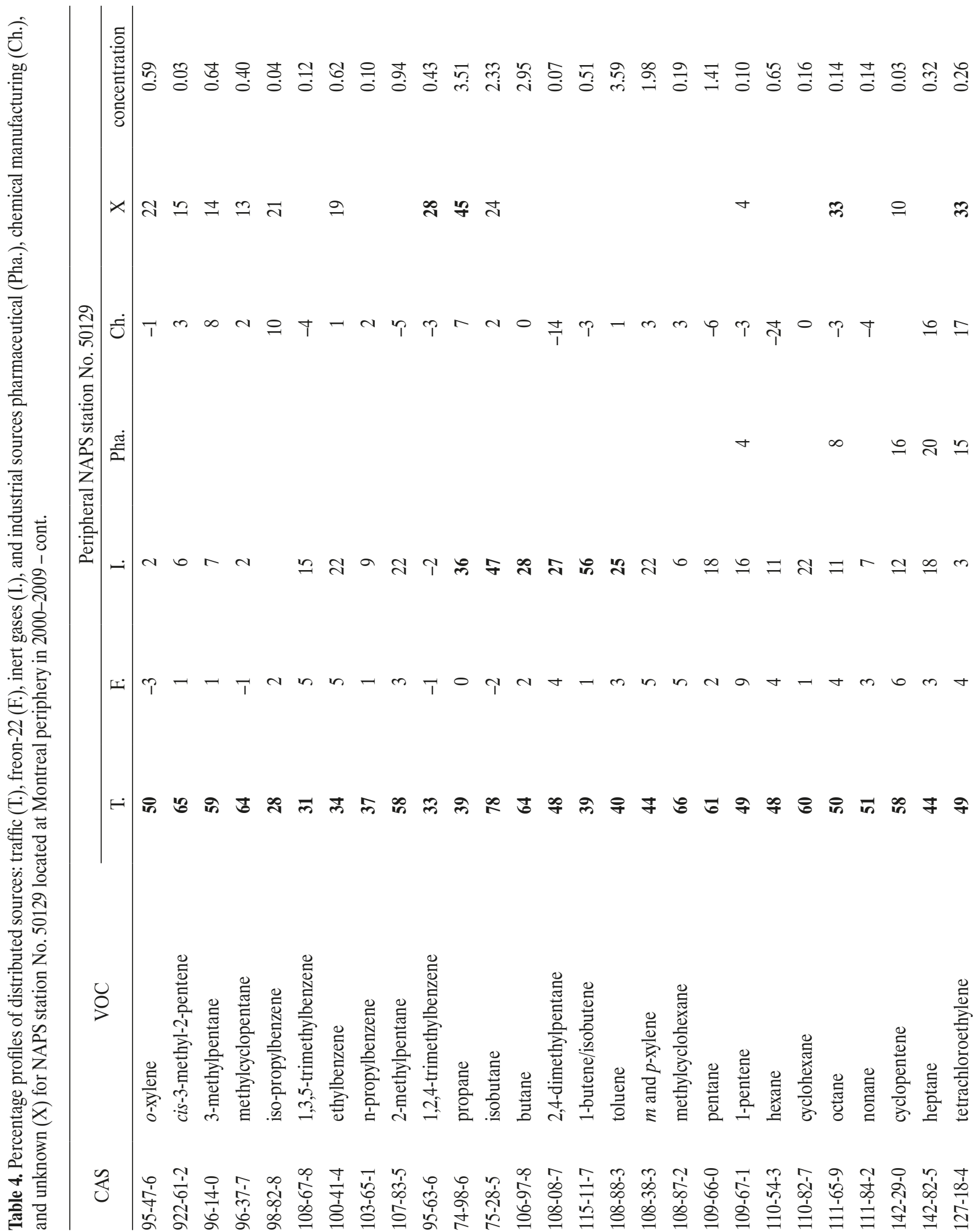




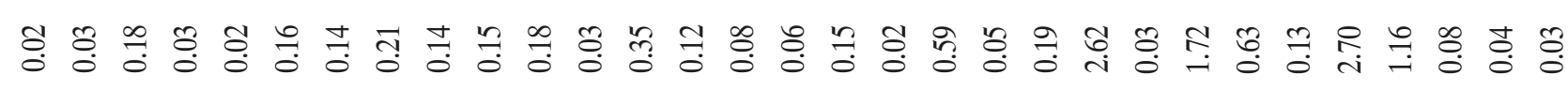

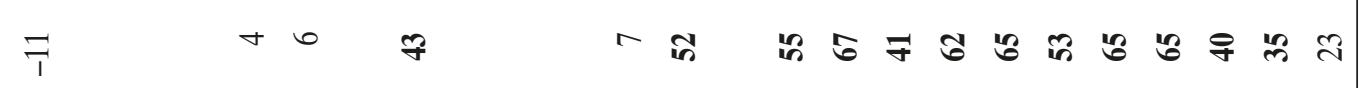

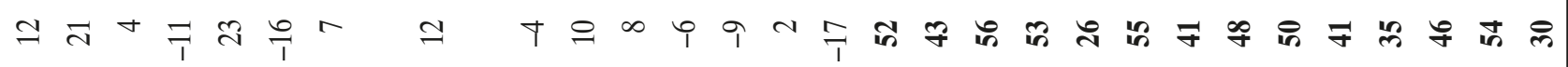

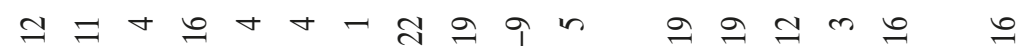

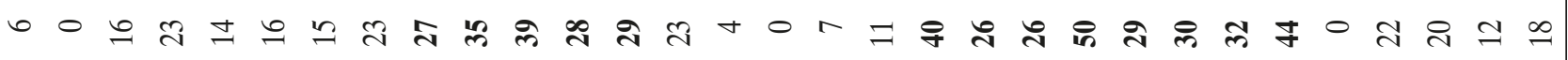

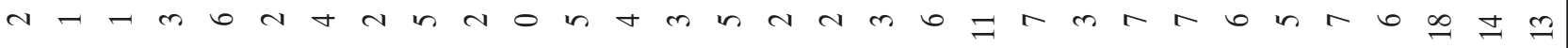
क in

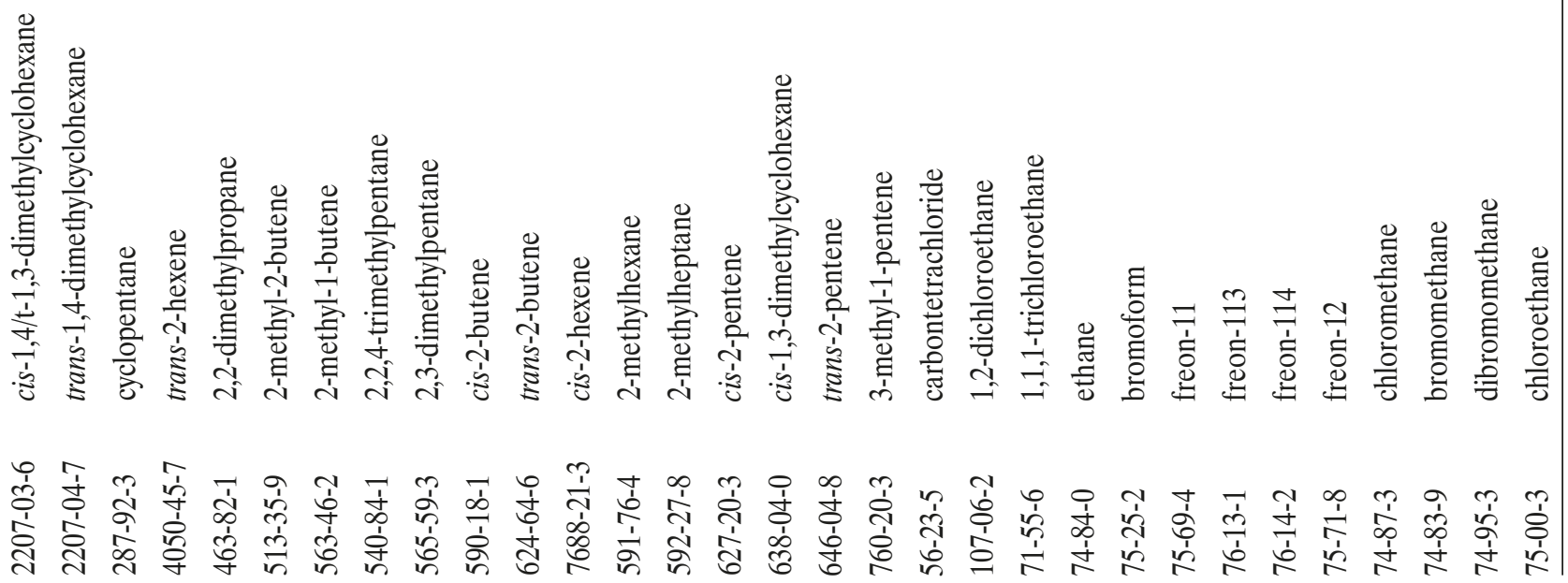




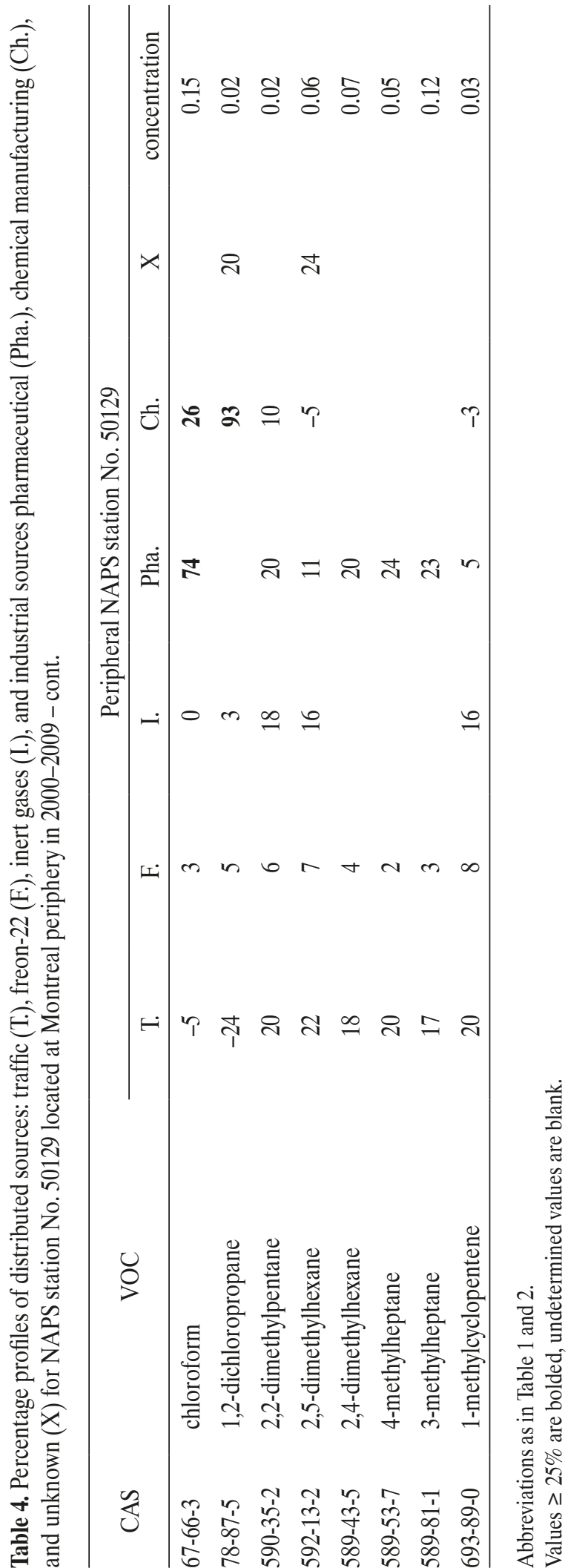

sources. This happens regardless of the efforts to curb their release into the environment [32,58,59]. Their presence in the environment is still a result of different product/waste streams coalescing in evaporations into atmosphere. The toxicity of trihalomethanes (chloroform, bromodichloromethane, dibromochloromethane, and bromoform) is widely discussed [60-67], but their usage as water disinfectant persists. They form in the atmosphere as a quite stable byproduct when chlorine is added to water to kill bacteria and, therefore, appear in each monitoring station. They are also used on a smaller scale in laboratories in chemical manufacturing [67,68].

Trichlorobenzenes are hardly detectable in the urban atmosphere in Montreal (they have a relatively short halflife in the atmosphere), and their possible source: volatilization from sediments and soils $[63,69-73]$ is not detected. Dichlorobenzenes (1,2-, 1,3-, 1,4-) appear in emissions from petrochemical factories and from manufacture of polymers, while chlorobenzene, the production of which in the U.S. declined considerably in the 2nd half of last century, is still detectable in emissions from automotive industries, where it is used as a solvent to degrease automobile parts [1].

Great restrictions on the use of chlorofluorocarbons (freons: $11,12,113,114)$ as refrigerants and propellants have been imposed since 1980 [14]. They have now been largely replaced by hydrochlorofluorocarbon freon-22. The chlorofluorocarbons, as very inert gases, still persist in the atmosphere accompanied by the abundant chlorinated hydrocarbons, chloroform and chloromethane, however, never in a company of freon-22. This suggests that sources of freon-22 and the ozone-depleting freons are different: the former has a source in the industry and in the consumer goods, while the latter ones are inert atmospheric vestiges of formerly massive releases from the wide industrial and consumer usage.

The Montreal "traffic" source, in comparison to the traffic in Mexico City [24] and locations in China [21-23], is more 
loaded with species related to octane content in the gasoline and to gasoline combustion products, such as ethylene. It is not clear whether the distinction reflects differences in urban transit technologies and/or in fuel additives or results of the methodology applied. The chloroethane used in leaded gasoline, but banned in Canada since 1980, disappeared from the traffic source. Its counterpart in the unleaded gasoline, methyl tert-butyl ether (MTBE), is also absent.

\section{Methodological aspects}

Factorization methods as PMF, but also UNMIX, preferentially treat the variables with higher average values. Therefore, the highest-concentration VOC species are given priority in emission profiles. The highest concentrations should be the 1st to divulge their sources, however, the UNMIX application also makes it possible to discern some lower-concentrations VOCs that persistently accompany the high-concentration species, providing chemical data, which facilitate identification of the sources.

The lowest-concentration VOCs are the most problematic, particularly when dealing with point sources: environmental influence of VOCs destroys the relationship between the source emission pattern and the measurements performed by a distant receptor. In the case of the distributed sources, the lowest-concentration VOCs tend to form noise-like background for the more prominent VOCs. UNMIX would refuse to produce results when the measurements cannot be reliably "unmixed" even when assuming "negative" sources, i.e., taking into account an environmental depletion of VOCs.

But, when with some VOC menu UNMIX achieves success, the measured VOC concentration becomes a sum of the positive inputs from VOC emissions by physical sources - reduced by VOC depletion due to reactions in the atmosphere. The removal of VOC, largely depending on the weather and not necessarily correlated with an input from a physical source, is represented as separate "negative" sources.
The "negative" sources present a complex picture and they require further investigation: preliminary seasonal analysis of the ambient concentrations of VOCs suggested that specific air masses could be responsible for affluence of some species, at the same time causing depletion of other species. If confirmed, this would explain the heterogeneous nature of sensor models generated with EPA UNMIX.

\section{ACKNOWLEDGMENTS}

The authors want to thank Dr. Mietek Szyszkowicz from Health Canada for the instructive discussions concerning our methodology and Janina Porada, MS, from the Abbott Corporation for her proof-reading of the chemical content. Environment Canada was very supportive when accessing their repositories of VOC data.

\section{REFERENCES}

1. Agency for Toxic Substances and Disease Registry. Atlanta: The Agency [updated 2008 Aug 14; cited 2014 Oct 31]. Chemical classification. Available from: http://www.atsdr.cdc.gov/ substances/ToxChemicalClasses.asp.

2. International Agency for Research on Cancer. Some industrial chemicals and dyestuffs. In: IARC Monographs on the evaluation of carcinogenic risks to humans. 1982 [cited 2014 Nov 2];29:1-416. Available from: http://apps.who. int/bookorders/anglais/detart1.jsp?sesslan $=1 \&$ codlan $=1 \&$ co $\mathrm{dcol}=72 \& \operatorname{codcch}=29$.

3. U.S. Environmental Protection Agency. Washington (DC): The Agency [updated 2013 Aug 8; cited 2014 Oct 31]. Evaluating exposures to toxic air pollutants: A citizen's guide (EPA 450/3-90-023). Available from: http://www.epa. gov/ttnatw01/3_90_023.html.

4. Wieslander G, Norback D, Edling C. Airway symptoms among house painters in relation to exposure to volatile organic compounds (VOCS) - A longitudinal study. Ann Occup Hyg. 1997;41:155-66, http://dx.doi.org/10.1093/ann hyg/41.2.155. 
5. Delfino RJ, Gong H Jr., Linn WS, Pellizzari ED, Hu Y. Asthma symptoms in Hispanic children and daily ambient exposures to toxic and criteria air pollutants. Environ Health Perspect. 2003;111:647-56.

6. Seinfeld JH, Pandis SN. Atmospheric chemistry and physics: From air pollution to climate change. 2nd ed. New York: Wiley Interscience; 2006. p. 38-54.

7. Elliott L, Longnecker MP, Kissling GE, London SJ. Volatile organic compounds and pulmonary function in the Third National Health and Nutrition Examination Survey, 19881994. Environ Health Perspect. 2006;114:1210-4, http:// dx.doi.org/10.1289/ehp.9019.

8. International Agency for Research on Cancer. 1,3-butadiene, ethylene oxide and vinyl halides (vinyl fluoride, vinyl chloride and vinyl bromide). In: IARC Monographs on the evaluation of carcinogenic risks to humans. 2008 [cited 2014 Nov 2];97:1-519. Available from: http://apps.who. int/bookorders/anglais/detart1.jsp?sesslan $=1 \&$ codlan $=1 \& \mathrm{c}$ odcol $=72 \& \operatorname{codcch}=97$.

9. U.S. Environmental Protection Agency. Washington (DC): The Agency [updated 2015 Apr 24; cited 2014 Oct 31]. Integrated Risk Information System. Available from: http:// www.epa.gov/iris/index.html.

10. Villeneuve PJ, Jerrett M, Su J, Burnett RT, Chen H, Brook J, Wheeler AJ, et al. A cohort study of intra-urban variations in volatile organic compounds and mortality, Toronto, Canada. Environ Pollut. 2013;183:30-9, http://dx. doi.org/10.1016/j.envpol.2012.12.022.

11. Atkinson R. Gas-phase tropospheric chemistry of organic compounds: A review. Atmos Environ. 1990;24A:1-41, http://dx.doi.org/10.1016/0960-1686(90)90438-S.

12. Atkinson R. Atmospheric chemistry of $\mathrm{VOC}$ and $\mathrm{NO}_{\mathrm{x}}$. Atmos Environ. 2000;34:2063-101, http://dx.doi.org/10.1016/ S1352-2310(99)00460-4.

13. Norman CS, DeCanio SJ, Fan L. The Montreal Protocol at 20: Ongoing opportunities for integration with climate protection. Glob Environ Change. 2008;18:330-40, http:// dx.doi.org/10.1016/j.gloenvcha.2008.03.003.
14. United Nations Environment Programme. Nairobi: The Programme; 2010-2011 [cited 2014 Nov 1]. The Montreal Protocol on substances that deplete the ozone layer. Available from: http://ozone.unep.org/new_site/en/montreal_protocol.php.

15. Srivastava A. Source apportionment of ambient VOCS in Mumbai city. Atmos Environ. 2004;38:6829-43, http:// dx.doi.org/10.1016/j.atmosenv.2004.09.009.

16. Olivier JGJ, van Aardenne JA, Dentener F, Pagliari V, Ganzeveld LN, Peters JAHW. Recent trends in global greenhouse gas emissions: Regional trends 1970-2000 and spatial distribution of key sources in 2000. Environ Sci. 2005;2: 81-99, http://dx.doi.org/10.1080/15693430500400345.

17. Kim E, Brown S, Hafner H, Hopke P. Characterization of non-methane volatile organic compound sources in Houston during 2001 using positive matrix factorization. Atmos Environ. 2005;39:5934-46, http://dx.doi.org/10.1016/j.atmos env.2005.06.045.

18. Buzcu B, Fraser M. Source identification and apportionment of volatile organic compounds in Houston, TX. Atmos Environ. 2006;40:2385-400, http://dx.doi.org/10.1016/ j.atmosenv.2005.12.020.

19. Reimann S, Lewis AC. Anthropogenic VOCs. In: Koppman R, editor. Volatile organic compounds in the atmosphere. Oxford: Blackwell Publishing Ltd; 2007. p. 33-81, http://dx.doi.org/10.1002/9780470988657.ch2.

20. Brown SG, Frankel A, Hafner HR. Source apportionment of $\mathrm{VOC}$ in the Los Angeles area using positive matrix factorization. Atmos Environ. 2007;41:227-37, http://dx.doi. org/10.1016/j.atmosenv.2006.08.021.

21. Song Y, Shao M, Liu Y, Lu S, Kuster W, Goldan P, et al. Source apportionment of ambient volatile organic compounds in Beijing. Environ Sci Technol. 2007;41:4348-53, http://dx.doi.org/10.1021/es0625982.

22. Song Y, Dai W, Shao M, Liu Y, Lu S, Kuster W, et al. Comparison of receptor models for source apportionment of volatile organic compounds in Beijing, China. Environ Pollut. 2008;156:174-83, http://dx.doi.org/10.1016/j.envpol. 2007.12.014. 
23. Liu Y, Shao M, Lu S, Chang Ch-Ch, Wang J-L, Fu L. Source apportionment of ambient volatile organic compounds in the Pearl River Delta, China: Part II. Atmos Environ. 2008;42:6261-74, http://dx.doi.org/10.1016/j.atmos env.2008.02.027.

24. Bon DM, Ulbrich IM, de Gouw JA, Warneke C, Kuster WC, Alexander ML, et al. Measurements of volatile organic compounds at a suburban groundside (T1) in Mexico City during the MILAGRO 2006 campaign: Measurement comparison, emission ratios, and source attribution. Atmos Chem Phys. 2011;11:2399-421, http://dx.doi.org/10.5194/acp-11-2399-2011.

25. Watson JG, Chow JC, Fujita EM. Review of volatile organic compound source apportionment by chemical mass balance. Atmos Environ. 2001;35:1567-84, http://dx.doi.org/10.1016/ S1352-2310(00)00461-1.

26. Scheff PA, Wadden RA. Receptor modeling of volatile organic compounds. 1. Emission inventory and validation. Environ Sci Technol. 1993;27:617-25, http://dx.doi.org/10.1021/ es00041a005.

27. Rosenbaum AS, Axelrad DA, Woodruff TJ, Wei Y, Ligocki MP, Cohen JP. National estimates of outdoor air toxic concentrations. J Air Waste Manag Assoc. 1999;49:1138-52, http://dx.doi.org/10.1080/10473289.1999.10463919.

28. Chang CC, Lo GG, Tsai CH, Wang JL. Concentration variability of halocarbons over an electronics industrial park and its implication in compliance with the Montreal protocol. Environ Sci Technol. 2001;35:3273-9, http://dx.doi. org/10.1021/es001894q.

29. Miller SL, Anderson MJ, Daly EP, Jana B. Milford JB. Source apportionment of exposures to volatile organic compounds. I. Evaluation of receptor models using simulated exposure data. Atmos Environ. 2002;36(22):3629-41, http:// dx.doi.org/10.1016/S1352-2310(02)00279-0.

30. Norris GA, Vedantham R, Duvall RM; U.S. Environmental Protection Agency. 2007 EPA UNMIX 6.0 user guide (EPA/600/R-07/089). Washington (DC) [cited 2013 Jan 19]. Available from: http:/www.epa.gov/heasd/documents/unmix-6-user-manual.pdf.
31. Environment Canada. Ottawa: Environment Canada; 1969 [updated 2013 Jun 9; cited 2014 May 1]. National Air Pollution Surveillance Program (NAPS). Available from: http://www.ec.gc.ca/rnspa-naps/.

32. Environment Canada. CEPA Ottawa: Environment Canada; 2014 [updated 2015 Apr 9; cited 2014 Nov 3]. Environmental registry. Available from: http://www.ec.gc.ca/lcpecepa/.

33. U.S. Environmental Protection Agency. Washington (DC): The Agency; 2004 [cited 2014 May 9]. The Clean Air Act. Available from: http://www.epw.senate.gov/envlaws/cleanair.pdf.

34. R Development Core Team [Internet]. R Foundation for Statistical Computing; Vienna: 2012 [cited 2012 Dec 4]. Available from: http://www.R-project.org/.

35. Mølhave L. Indoor air pollution due to organic gases and vapors of solvents in building materials. Environ Int. 1982;8:117-27, http://dx.doi.org/10.1016/0160-41 20(82)90019-8.

36. Robins GA, Deyo BG, Temple MR, Stuart JD, Lacy MJ. Soil-gas surveying for subsurface gasoline contamination using total organic vapor detection instruments Part 1. Theory and laboratory experimentation. Ground Water Monit R. 1990;10:122-31, http://dx.doi. org/10.1111/j.1745-6592.1990.tb00011.x.

37. Jones VT, Burtell SG. Soil vapor - Petroleum product constituents contained in near surface soils and/or groundwater. Hydrocarbon flux variations in natural and anthropogenic seeps. In: Schumacher D, Abrams MA, editors. Hydrocarbon migration and its near surface expression. AAPG Memoir. 1996;66:203-21.

38. Fischer ML, Bently AJ, Dunkin KA, Hodgson AT, Nazaroff WW, Sextro RG, et al. Factors affecting indoor air concentrations of volatile organic compounds at a site of subsurface gasoline contamination. Environ Sci Technol. 1996;30:2948-57, http://dx.doi.org/10.1021/es950912e.

39. Pankow JF, Thomson NR, Johnson RL, Baehr AL, Zogorski JS. The urban atmosphere as a non-point source for 
the transport of MTBE and other volatile organic compounds (VOC's) to shallow groundwater. Environ Sci Technol. 1997;31:2821-8, http://dx.doi.org/10.1021/es970040b.

40. Tang L, Tang X-Y, Zhu Y-G, Zheng M-H, Miao Q-L. Contamination of polycyclic aromatic hydrocarbons (PAHs) in urban soils in Beijing, China. Environ Int. 2005;31:822-8, http://dx.doi.org/10.1016/j.envint.2005.05.031.

41. U.S. Environmental Protection Agency. The Agency; 2009 [updated 2013 Jun 20; cited 2014 Nov 1]. IRIS Toxicological review of trichloroethylene (TCE) (external review draft). Available from: http://cfpub.epa.gov/ncea/cfm/ recordisplay.cfm?deid $=215006$.

42. Weber M, Weber M, Kleine-Boymann M. Phenol. In: Ullmann's encyclopedia of industrial chemistry. Weinheim: Wiley-VCH; 2004 [cited 2014 Nov 2], http:/dx.doi.org/ 10.1002/14356007.a19_299.pub2.

43. Encyclopedia.com [Internet]. The Columbia Encyclopedia. Chlorofluorocarbons. 6th ed. 2014 [cited 2014 Jul 18]. Available from: http://www.encyclopedia.com/doc/1E1-chlorofl.html.

44. Rossberg M, Lendle W, Pfleiderer G, Tögel A, Dreher E-L, Langer E, et al. Chlorinated hydrocarbons. In: Ullmann's encyclopedia of industrial chemistry. Wiley-VCH; 2011 [cited 2015 Jun 12]. Available from: http://onlinelibrary.wiley. com/doi/10.1002/14356007.a06_233.pub3/abstract.

45. James DH, Castor WM. Styrene. In: Ullmann's encyclopedia of industrial chemistry. Wiley-VCH; 2011 [cited 2014 Nov 2]. Available from: http://dx.doi.org/10.1002/14356007. a25_329.pub2.

46. American Petroleum Institute [Internet]. Washington (DC): The Institute Adventures in Energy: Refining oil; 1990 [cited 2013 Jun 8; about 7 screens]. Available from: http://www. adventuresinenergy.org/Refining-Oil/Blending_vapor.html.

47. United States Department of Labor. Washington (DC): The Department; 1999 [cited 2014 Nov 2]. OSHA Technical Manual Sec. IV Ch. 2: Petroleum refining processes. Available from: https://www.osha.gov/dts/osta/otm/otm_iv/ otm_iv_2.html.
48. Australian Institute of Petroleum. Canberra: The Institute; 1976 [cited 2013 Jun 18]. Industry information: Refining of petroleum. Available from: http://www.aip.com.au/ industry/fact_refine.htm.

49. Zimmermann H, Walzl R. Ethylene. In: Ullman's encyclopedia of industrial chemistry; Wiley-VCH; 2009 [cited 2014 Nov 2]. http://dx.doi.org/10.1002/14356007.a10_045.pub3.

50. Dumitriu E, Melonib D, Monacib R, Solinasb V. Liquidphase alkylation of phenol with t-butanol over various catalysts derived from MWW-type precursors. C R Chim. 2005;8:441-56, http://dx.doi.org/10.1016/j.crci.2004.10.007.

51. Ghiaci M, Aghabarari B. Vapor-phase alkylation of phenol with tert-butyl alcohol catalyzed by H3PO4/MCM-41. Chin J Catal. 2010;31:759-64, http://dx.doi.org/10.1016/ S1872-2067(09)60085-1.

52. Zhang FF, van Rijnman T, Kim JS, Cheng A. On present methods of hydrogenation of aromatic compound, 1945 to present day. Lund: Lunds Tekniska Hogskola; 2008.

53. Nobel Lecture. Sabatier P. The method of direct hydrogenation by catalysis. Nobel lecture, Dec 11, 1912 [cited 2013 Jul 22]. Available from: http://www.nobelprize.org/nobel_ prizes/chemistry/laureates/1912/sabatier-lecture.html.

54. Garcia VP, Tabe-Mohammadi A. A review on the separation of benzene/cyclohexane mixture by pervaporation process. J Membrane Sci. 2000;169:159-74, http://dx.doi. org/10.1016/S0376-7388(99)00337-3.

55. Hamid SH, Ali MA. Comparative study of solvents for the extraction of aromatics from naphtha. Energ Source. 1996; 18:65-84, http://dx.doi.org/10.1080/00908319608908748.

56. McGuinness DS, Wasserscheid P, Keim W, Morgan D, Dixon JT, Bollmann A, et al. First Cr(III)-SNS complexes and their use as highly efficient catalysts for the trimerization of ethylene to 1-hexene. J Am Chem Soc. 2003;125:5272-3, http://dx.doi.org/10.1021/ja034752f.

57. Reichardt C. Solvents and solvent effects in organic chemistry. 2nd ed. Weinheim: Wiley-VCH; 1988.

58. U.S. Environmental Protection Agency. Washington (DC): The Agency; 1991 [updated 2015 May 4; cited 2014 Sep 20]. 
Canada-United States Air Quality Agreement. Available from: http://www.epa.gov/airmarkets/progsregs/usca/index.htm.

59. Environment Canada and Heath Canada. Ottawa: Environment Canada and Heath Canada; 2001 [updated 2013 Aug 20; cited 2013 Aug 29]. Canadian Environmental Protection Act, 1999. Available from: http:/www.ec.gc.ca/toxiques-toxics/.

60. Pereira MA, Lin LH, Lippitt JM, Herren SL. Trihalomethanes as initiators and promoters of carcinogenesis. Environ Health Perspect. 1982;46:151-6.

61. Health Canada. Guidance on chloral hydrate in drinking water. Ottawa: Health Canada; 2008 [cited 2014 Nov 1]. Available from: http://www.hc-sc.gc.ca/ewh-semt/pubs/water-eau/ chloral_hydrate-chloral/index-eng.php.

62. Williams DT, LeBel GL, Benoit FM. Disinfection by-products in Canadian drinking water. Chemosphere. 1997;34:299316, http://dx.doi.org/10.1016/S0045-6535(96)00378-5.

63. Health Canada. Priority substances list assessment report for chloroform. Ottawa: Health Canada; 2001 [cited 2014 Nov 1]. Available from: http://www.hc-sc.gc.ca/ewh-semt/ pubs/contaminants/psl2-lsp2/chloroform/index-eng.php.

64. International Programme on Chemical Safety. Environmental Health Criteria 216. Disinfectants and disinfectant byproducts. Geneva: World Health Organization; 2000.

65. King WD, Dodds L, Allen AC. Relation between stillbirth and specific chlorination by-products in public water supplies. Environ Health Perspect. 2000;108:883-6.

66. Hrudey SE. Chlorination disinfection by-products, public health risk tradeoffs and me. Water Res. 2009;43:2057-92, http://dx.doi.org/10.1016/j.watres.2009.02.011.

67. U.S. Environmental Protection Agency. Chemical summary for 1,2,4-trimethylbenzene. Washington (DC): The
Agency; 1994 [cited 2013 Jul 3]. Available from: http://www. epa.gov/chemfact/s_trimet.txt.

68. Health Canada. Guidelines for Canadian drinking water quality: Guideline technical document: Trihalomethanes. Ottawa: Health Canada; 2006 [cited 2014 Nov 1]. Available from: http://www.hc-sc.gc.ca/ewh-semt/pubs/water-eau/triha lomethanes/index-eng.php.

69. Health Canada. Priority substances list assessment report for trichlorobenzenes. Ottawa: Health Canada; 1993 [cited 2013 Sep 1]. Available from: http://www.hc-sc.gc.ca/ewhsemt/pubs/contaminants/psl1-lsp1/trichlorobenzenes/indexeng.php.

70. U.S. Environmental Protection Agency. Locating and estimating air emission from sources of chlorobenzenes (revised) (EPA-454/R-93-044). Office of air quality planning and standards. Research Triangle Park (NC): The Agency; 1994 [cited 2013 Sep 1]. Available from: http://www.epa. gov/ttnchie1/le/chlorbnz.pdf.

71. National primary drinking water regulations: Disinfections and disinfection byproducts; final rule. 40 CFR Parts 9, 141, and 142 (1998) [cited 2014 Nov 1]. Available from: http:// water.epa.gov/lawsregs/rulesregs/sdwa/mdbp/dbpfr.cfm.

72. World Health Organization. Environmental health criteria 216: Disinfectants and disinfectant by-products. Geneva: WHO; 2000 [cited 2013 Sep 1]. Available from: http:// www.inchem.org/documents/ehc/ehc/ehc216.htm.

73. World Chlorine Council. World Chlorine Council position paper: Drinking water chlorination. The Council; 2008 [cited 2013 Jul 30]. Available from: http://www.worldchlorine. org/wp-content/themes/brickthemewp/pdfs/WCC_Policy_ Paper_Water_Chlorination.pdf.

This work is available in Open Access model and licensed under a Creative Commons Attribution-NonCommercial 3.0 Poland License - http://creativecommons.org/ licenses/by-nc/3.0/pl/deed.en. 